\title{
Detection of Possible Tax-Evasive Transfer Pricing in Multinational Enterprises $^{\#}$
}

\author{
Jaroslav BRADA* ${ }^{*}$ Tomáš BUUS ${ }^{* *}$
}

\section{Introduction}

Literature on transfer pricing was quite rare for a long time - until the $7^{\text {th }}$ decade of the $20^{\text {th }}$ century. One for all we shall mention (Schmallenbach, 1908) and (Hirshleifer, 1956), which created the theoretical base for further research. With the growth of importance of multinational enterprises (MNEs) and economical globalization the significance of transfer pricing issues grows. The obstacle to better understanding of transfer pricing is that transfer pricing is considered to be confidential issue at most MNEs. Thus empirical studies are rare, though number of theoretically aimed articles in the recent past (nineties of the $20^{\text {th }}$ century) is pleasant.

Both the newer and the older literature deals mainly with following problems:

1. the general problems of central setting of the transfer price,

2. preference of the system of transfer pricing (centralized or decentralized),

3. impact of information asymmetry and managers' compensation,

4. optimization of transfer pricing with respect to taxes and other criteria,

5. regulation of transfer pricing.

\# The article is processed as an output of a research project Regulation of Transfer Pricing registered by the Czech Science Foundation under the registration number 402/08/027.

Doc. Ing. Jaroslav Brada, Ph.D. - associate professor; Department of Monetary Theory and Policy, Faculty of Finance and Accounting, University of Economics, Prague, W. Churchill sq. 4, 13067 Prague, Czech Republic; <brada@vse.cz>.

** Ing. Tomáš Buus, Ph.D. - assistant professor; Department of Corporate Finance and Valuation, Faculty of Finance and Accounting, University of Economics, Prague, W. Churchill sq. 4, 13067 Prague, Czech Republic; <buust@vse.cz>. 
The first mentioned theme has been discussed in the literature quite a long time, but we are afraid to say that in most cases it is a solution based on using of similar methods and assumptions (which are sometimes widened or narrowed), but the results are in most cases similar to the pioneering articles, from the point of view of the conclusions of general problems of transfer pricing. Due to articles (Smallenbach, 1908/1909) and newly (Hirshleifer, 1956) are still in the microeconomic textbooks used theses that the most appropriate transfer price in the vertically integrated MNE are the marginal costs of intermediate product. We can give some examples like (Pappas, Brigham and Hirschey, 1983), (Soukup, 2003), among articles in journals (Gatti, Grinell and Jensen, 1997) or (Baldenius, Melumad and Reichelstein, 2004) as examples. This theory is in our opinion in contrast with the contemporary business practice and it is based on assumptions, which do not hold in practice. The evident collision of the marginal cost transfer pricing theory can be shown in case of (OECD, 2001). We have concluded in (Buus and Brada, 2008) that the optimal transfer price from the point of view of resource allocation and efficient production of intermediate product is under neoclassical assumptions the average cost of intermediate product.

The methods of transfer pricing advised to be used in OECD countries are (among others):

1. arms-length method,

2. cost plus method,

3. formula apportionment method,

4. profit split method,

which in all cases directly or indirectly use a premise that the fair transfer price is on the level of price achieved at the market transaction, which equals to marginal cost only in the extraordinary cases (perfectly competitive market of the intermediate product). If there is no market for intermediate product, the cost-plus method is used. Mentioned cost-plus method does not use marginal cost, but the average cost of intermediate product. These can be also the optimal solution, which does not require some necessary conditions used or implied by articles deriving the optimality of marginal cost transfer pricing, as Buus and Brada (2008) show.

Otherwise the contemporary literature aims rather on the information asymmetry, integration of manager's and tax objectives or setting of the 
optimal transfer price with respect to the particular problems of financial management.

The problem of transfer prices and their effect on the possibility of active fiscal policy is compelling as Bartelsman and Beetsma (2003) show. Nevertheless the number and size of possible tax evasions is greater at commodities, which are not standardized (not quoted), whereas at the commodities traded at the commodity exchanges the variance of transfer price and difference between transfer price and arms-length price is substantially smaller (Bernard, Jensen and Schott, 2006), which can be nevertheless interpreted similarly as some of the conclusions of (Gresik, 2001) - there, where the MNE has an advantage against the tax authority due to the information asymmetry, is the space for larger tax evasions. Even the measurement becomes a problem in the contemporary globalized world, because the size of transactions inside MNE is so tremendous that it influences the benchmarks used for derivation of armslength price (Eden and Rodrigues, 2004).

Indeed the situation is worsened by governments themselves, because due to the attempt to achieve as high as possible tax income they continuously tighten transfer pricing regulation rules, which leads to the double taxation and depression of international trade or on the other hand (depending upon the way, which the national tax legislations chose) to the harmful tax competition, as Raimondos-Moller and Scharf (2002) or Mansori and Weichenrieder (1999) conclude. Raimondos-Moller and Scharf (2002) also derive the condition of Pareto-optimal transfer pricing regulation solution - harmonization of behavior of particular national tax authorities under conditions of compliance with Nash equilibrium conditions. We think that it would be desirable to find a mechanism ensuring the equilibrium even in the conditions of non-cooperative behaviour of tax authorities.

Further we can find literature discussing the effectiveness of particular methods of transfer pricing regulation. For example Sansing (1999) concludes that method of transfer pricing regulation systematically influences profit allocation and that methods based on profit split or profit margin act in favour of the countries with higher taxation in this case. Similarly Schjelderup and Weichenrieder (1999) conclude that the use of methods based on profit split causes distortions in the pricing and international trade. Wellisch (2003) concludes that standard methods 
(arms-length price based methods) cause suboptimal results of decisionmaking.

In our last paper (Buus and Brada, 2008) we have provided comparison of transfer pricing techniques proposed by OECD (2001) transfer pricing guidelines. The result was that the only transfer pricing methods, which do not distort prices and thus do not lead to pressure to produce lower or higher than optimal quantity of intermediate product (or in other words, which does not cause departure of tax-optimal and profit-optimal quantity of production) is Cost+ method or Comparable Resale Price method with percentage markup/discount. Other methods distort optimal quantity, while the most distortive method was profit split method. We have gained these results using simulation on maximization of profit and tax revenue, while having only profit taxed. It is however clear that the above conclusions about optimality of transfer pricing methods are valid also for other taxes used for taxation of factor cost (capital, labour).

With respect to the contemporary practice and theoretical findings and with respect to the importance of MNEs we consider to be highly desirable to widen the theory of transfer pricing and derive a solution for transfer pricing regulation, that will lead to Pareto-optimal equilibrium even in the case of non-cooperative behavior of particular tax authorities. It can be shown on the latest steps of CEE governments (and even the German government) leading to lower corporate income tax rates, that we cannot expect a cooperative behavior.

When looking for literature, which would help us, we concluded that we would probably have to rely on our own. Firstly the literature on transfer pricing in vertically integrated industries mostly recognizes the marginal cost as the best transfer price (as could be seen above). Secondly most of the conclusions based on which an optimal taxation system could have been found do not deal with transfer pricing (e.g. Haufler and Schjelderup, 2000 examine taxation of capital or Keen and Wildasin, 2004 examine tax systems in general). Bond and Samuelson (1989) derive that the preferred tax scheme are tax deductions, which are preferred to tax credits, because of distortive potential of tax credits. The most suitable conclusions from our point of view were derived in (Raimondos-Moeller and Scharf, 2002), that the harmonization of transfer pricing rules leads to Pareto-optimization. These conclusions in some cases rely on an assumption that taxation is an instrument to get resources 
for provision of services (possibly public goods), therefore taxation itself is not harmful.

In the subsequent part of paper we show that tax base of whole MNE depends on the ownership structure companies included in MNE and motivation to use tax-evasive transfer pricing depends on the ability to shift tax base among MNE members. We also set up indicator, which could be used as the estimator of possible tax evasion via transfer prices within the whole MNE. However, in this paper does not look into ways of finding possible tax evaders among various types of MNE in given economy.

\section{Model of tax optimization of MNE}

In this part of paper we describe setup of simple model of optimal economic behaviour of companies included in MNE while assuming maximization of net profit of whole MNE - via shifting tax base through transfer prices. Based on model of optimal economic behaviour of companies within MNE we setup indicator of potential tax evasion rate i.e. indicator or potential transfer prices using in the whole MNE. For the methodology of advanced linear algebra could we have used, please look at e.g. (Steven, 2005).

Terms used in model:

$M N E$ multinational enterprises - group of companies, which existing in different countries are subject to various tax conditions. Members of MNE coordinate their economic activities in order to achieve maximal profit of the whole MNE. In this paper we consider profit maximization being achieved via reducing special costs - tax cost, which is paid by every member of MNE.

- tax base For simplicity we assume that tax base is the same as EBT (Earnings Before Tax) and that tax base of every member company of MNE is nonnegative and total sum of all companies tax bases are positive.

- tax entity group of firms (usually members of MNE), which coordinate their economic activities in order to achieve total sum of payable taxes as low as possible. From the point of view of pure economic theory there is not important whether tax entity is 
also some type of "legal entity" or just some group of firms, which coordinates their economic activities on base of gentlemen agreements. For simplicity we assume that tax entity is subject of MNE and MNE simply consist group of legally co-owned companies. MNE is therefore possible to describe as matrix of owners relations. Note: Without loss of generality also other type of MNE is possible to describe as "owner's rights" - matrix where "owner's rights" are not subject any type of legal arrangements. I.e. members MNE could reduce tax base by coordination prices for goods and services among companies within MNE.

Let us denote:

$n$ = number of firms, which are members of MNE.

$\boldsymbol{M}=$ matrix is $n \times \mathrm{x} n$ matrix, which fully describes ownership structure of MNE. $\boldsymbol{M}=\left[m_{i, k}\right]$, where $i^{\text {th }}$ row denotes that $i^{\text {th }}$ firm own share (eg: trade deal, share deal, authorized capital deal and so on) in $k^{\text {th }}$ firms, $m_{i, k} \in[0,1]$. (Note: Crossownership could be included in matrix $M$ too. For example when $m_{1,3}=0.1$ (i.e. $10 \%$ of own share) and $m_{3,1}=0.2$ then firm 1 owned $10 \%$ of firm 3 and firm 3 owned $20 \%$ of firm 1.) By definition diagonal elements $m_{k, k}(k=1,2, \ldots, n)$ represents share (in authorized capital of $k^{\text {th }}$ company) which is held by firms which are not described by matrix $\mathrm{M}-$ i.e. share on $k^{\text {th }}$ company, which could be held by any economic subject "outside matrix M".

= Note: In the above-described matrix $M$ is therefore not allowed to any company held own share (on authorized capital) - .e. $k^{\text {th }}$ company does not have any share (e.g. on authorized capital) in itself! Diagonal matrix $M$, where on diagonal are only 1 , describes multinational enterprise, where the only owner on shares of subsidiaries within MNE is the headquarters (but there can be other owners of those shares outside MNE). For simplification of our text let be $m_{k, k}(k=1$, $2, \ldots, n)$ called free shares, i.e. e.g. shares which could be used for "building special portfolio of shares" which is called usually "Multinational Entity". 
$\bar{v}=$ column vector, which describes part of shares of subsidiaries, which is directly owned by MNE headquarters - i.e. row vector $\bar{v}^{T}=\left[v_{1}, v_{2}, \ldots, v_{n}\right]$, where $v_{k} \in[0,1]$ represents relative share at free shares. (Eg.: $\mathrm{m}_{1,1}=0.7, \mathrm{~m}_{2,2}=0.5, m_{3,3}=0.8-$ then vector $\bar{v}^{T}=[1 ; 1 ; 0.5]$ represents situation when MNE owns own share such that $70 \%$ of firm $1,50 \%$ of firm 2 and $40 \%$ of firm 3. Clearly situation when vector $\mathrm{r} \bar{v}^{T}=[1,1,1]$ denoted that MNE owned $70 \%$ of firm 1, 50\% of firm 2 and $80 \%$ of firm 3 - i.e. that MNE from pure economic view own directly or indirectly full $100 \%$ of free shares of all three firms! From point of view of mathematical model vector $\bar{v}$ describes the top level of MNE ownership (relative to free share).

$\mathbf{E}=$ unit matrix $\left(e_{k, k}=1, e_{k, r}=0 k \neq r\right.$ for $\left.k, r=1,2, \ldots, \mathrm{n}\right)$.

$\bar{l}=$ column vector of real numbers 1 (so called summation vector), i.e. $\overline{1}^{T}=[1,1, \ldots, 1]$.

$\bar{t}=$ column taxation vector, i.e. $\bar{t}^{T}=\left[t_{1}, t_{2}, \ldots, t_{n}\right]$, where $t_{k}$ is tax rate of $k^{\text {th }}$ company ( $k^{\text {th }}$ members of MNE) Even if this paper is oriented on MNE in the presented here model is not necessary to assume that different companies have to be in different countries and also not only corporate income tax should be considered (VAT taxes, payroll taxes, etc.).

$\boldsymbol{W}=$ diagonal $n \times n$ matrix describes taxation of members of MNE. On diagonal is taxation vector $\mathbf{W}=\left[w_{i, k}\right], w_{k, k}=t_{k}, w_{k, r}=0$ for $r \neq k$ where $k, r=1,2, \ldots, n, \bar{t}^{T}=\left[t_{1}, t_{2}, \ldots, t_{n}\right]$ is taxation vector, and $t_{k}$ is tax rate of $k^{\text {th }}$ company.

$\bar{z}=$ column tax-base vector, i.e. $\bar{z}^{T}=\left[z_{1}, z_{2}, \ldots, z_{n}\right]$, where $z_{k}$ is taxbase of $k^{\text {th }}$ company (members of MNE). This vector is fully observed from reality and it is known (eg. on the base of statement of taxable income) fully observed, i.e. $\bar{z}$ is vector of parameters. For simplicity we assume that tax-base is the same as EBT (EBT - Earnings Before Taxes) and tax-base vector $\bar{z}^{T} \neq \overline{0}^{T}$ and $z_{k} \geq 0 k=1,2, \ldots, n$ (i.e. MNE generates positive profit.). 
t_tax $=$ is total amount of tax paid by whole MNE in matrix form, i.e. $t_{-} \operatorname{tax}=\bar{v}^{T} M W \bar{z}$.

$t \_N E T=$ total amount of net profit attributable to MNE (in matrix form) i.e.

$$
t_{-} N E T=\bar{v}^{T} M(E-W) \bar{z} .
$$

This scalar (value) is fully observable from reality and it is known (usually from various tax forms).

$$
\begin{aligned}
\overline{1}^{T} M \bar{z}= & \text { total sum of EBT of all companies in MNE - i.e. this } \\
& \text { amount can not be influenced by taxation of EBT in single } \\
& \text { companies. }
\end{aligned}
$$

Let be further vector of (unknown) variables:

$$
\begin{aligned}
\bar{x}= & \text { column tax-base vector, i.e. } \bar{x}^{T}=\left[x_{1}, x_{2}, \ldots, x_{n}\right], \text { where } x_{k} \text { is } \\
& \text { tax-base of } k^{\text {th }} \text { company (members of MNE) which could be } \\
& \text { subject of changes. This vector is therefore vector of } \\
& \text { variables, which could be subject to profit shifting among } \\
& \text { MNE members via transfer pricing. We still assume that tax } \\
& \text { base is the same as EBT (EBT }- \text { Earnings Before Taxes) } \\
& \text { and tax base vector } \bar{x}^{T} \neq \overline{0}^{T} \text { and } x_{k} \geq 0 ; k=1,2, \ldots, n \text { (i.e. at } \\
& \text { least one company of MNE generates positive profit.). }
\end{aligned}
$$

From pure view of theory every MNE could solve two important tasks:

1. maximize total net profit of MNE and

2. minimize total net profit of MNE.

While solving both MNE is bound by fact that total sum of ot EBT of all companies which are included in MNE is the same.

Hence it follows:

1. MNE maximizes total amount of its own net profit

$$
\bar{v}^{T} M(E-W) \bar{x} \rightarrow \max _{\bar{x}}
$$


with respect to

$$
\bar{x}^{T} \overline{1}=\overline{1}^{T} M \bar{z}, \bar{x} \geq \overline{0} .
$$

Let be optimal solution (i.e. column vector of real numbers) of this task denoted $\bar{x}_{\text {max }}^{*}$. The smallest total sum of all tax paid by MNE (via MNE shares in various companies) is then

$$
\bar{v}^{T} M W \bar{x}_{\max }^{*} .
$$

2. MNE minimizes total amount of its own net profit

$$
\bar{v}^{T} M(E-W) \bar{x} \rightarrow \min _{\bar{x}}
$$

with respect to

$$
\bar{x}^{T} \overline{1}=\overline{1}^{T} M \bar{z}, \quad \bar{x} \geq \overline{0} .
$$

Let be optimal solution (i.e. column vector of real numbers) of this task denoted $\bar{x}_{\text {min }}^{*}$. The largest possible total sum of all tax paid by MNE (via MNE shares in various companies) is then

$$
\bar{v}^{T} M W \bar{x}_{\min }^{*} .
$$

Then $\bar{v}^{T} M W \bar{z}$ is total amount of tax paid in reality by whole MNE.

\section{Economic result of model}

From the point of view of common practice of various tax authorities it is necessary to answer two important questions:

1. Is it possible to assume that profit is shifted via transfer prices among companies inside MNE?

2. Is it possible to find companies in MNE between which profit is shifted via transfer prices? 
Answer of the first question is quite easy. On the base of above solved optimization tasks looks be acceptable to define indicator, which could be considered as measure of potential rate of tax evasion as follows

$$
\text { TaxEvasionRate }=1-\frac{\bar{v}^{T} M W \bar{z}-\bar{v}^{T} M W \bar{x}_{\min }^{*}}{\bar{v}^{T} M W \bar{x}_{\max }^{*}-\bar{v}^{T} M W \bar{x}_{\min }^{*}} \in[0,1],
$$

where by economic assumption $\bar{x} \geq \overline{0}, \bar{x} \neq \overline{0}$.

Level of TaxEvasionRate close or equal 0 (zero) indicates that there is almost surely none tax evasion committed by analyzed MNE and TaxEvasionRate close to 1 indicates that there could be some tax evasion in MNE - i.e. tax paid by whole MNE is very low. We stress the expression "could be", because the proposed indicator shows only overall taxation of MNE and compliance or non-compliance with transfer pricing guidelines is the only acceptable proof for court. So the proposed indicator is a preliminary measure for tax authorities, but possibly very efficient measure for further research.

Answer to the second question is rather more complicated and less clear than the first one. If there were no penalties for tax evasion, $\bar{x}_{\min }^{*}$ and $\bar{x}_{\max }^{*}$ would be zero vector in which one item is positive (corner solution). This is direct consequences fact that both optimized functions are linear and constraints are linear too. More mathematical proofs and more detailed specification conditions of validity of this fact are beyond scope this paper. Nevertheless in the following text we will assume that there could be more positive items in optimal solutions vectors.

Vector $\bar{x}_{\text {min }}^{*}$ indicates situation of spreading the tax bases among member companies of MNE from point of view of tax authority - when MNE pays the highest taxes and vector $\bar{x}_{\max }^{*}$ indicates situation when MNE pays the lowest taxes.

Positive items (e.g. 4th item is 4th company of MNE) in vector $\bar{x}_{\text {min }}^{*}$ (i.e. highest taxes paid by MNE in total) indicate situation that e.g. 4th company could possibly want to reduce all positive items in real vector tax base $\bar{z}$ too - i.e. there is potential pressure to reduce positive items in 
vector $\bar{z}$ at the same position as positive items in vector $\bar{x}_{\text {min }}^{*}$ - via buying for inflated prices or selling for artificially deflated prices.

Positive items in vector $\bar{x}_{\max }^{*}$ (i.e. lowest taxes paid by MNE in total) indicate situation that such company could possibly want to increase items in vector $\bar{z}$ at the same that were found to be positive in vector $\bar{x}_{\max }^{*}$. Therefore we can suspect that MNE will try to increase tax base of these companies via buying for artificially deflated prices or selling for artificially inflated prices.

For example: If $\bar{x}_{\max }^{* T}=(0 ; 1000 ; 0 ; 0)$ and $\bar{x}_{\min }^{*}=(0 ; 0 ; 0 ; 1000)$ and $\bar{z}^{T}=(50 ; 200 ; 300 ; 450)$ the company "Nr. 2 " (second position in vector $\bar{x}_{\max }^{*}$ ) might want to increase own tax base et vice versa for the company "Nr. 4" (fourth position in vector $\bar{x}_{\text {min }}^{*}$ ) I.e. for tax authorities (or tax authority) would be appropriate to analyze sell and buy prices of company "Nr. 4" and sell and buy prices of company "Nr. 2" also, the other are not so significant. For the sake of reducing of total amount of total tax paid by MNE we might expect to shift profit between companies "Nr. 2" and "Nr. 4".

\section{Conclusions}

In the presented paper we have shown that tax base of whole MNE depends on the ownership structure of companies contained in MNE, which could be described in quite simply matrix form. It was shown that basic tax optimization tasks of MNE are the linear programming problems. In addition we have developed formula (the indicator) of potential tax rate evasion (i.e. tax evasion of bundle firms which are joined in MNE).

\section{References}

[1] Baldenius, T. - Melumad, Nahum D. - Reichelstein, Stefan J. (2004): Integrating Managerial and Tax Objectives in Transfer Pricing. Accounting Review, 2004, vol. 79, no. 3, pp. 591-615.

[2] Bartelsman, E. J. - Beetsma, R.M.W.J. (2003): Why Pay more? Corporate Tax Avoidance through Transfer Pricing in OECD 
Brada, J. - Buus, T.: Detection of Possible Tax-Evasive Transfer Pricing in Multinational Enterprises.

Countries. Journal of Public Economics, 2003, vol. 87, no. 9, pp. 2225-2252.

[3] Bernard, A. B. - Jensen, J.B. - Schott, P. K. (2006): Transfer Pricing by U.S.-based Multinational Firms. [on-line], Washington, D.C., National Bureau of Economic Research Working paper 12493, c2004, [cit. $1^{\text {st }}$ October, 2009], <http://papers.nber.org/papers/w12493.pdf>

[4] Bond, E. W. - Samuelson, L. (1989): Strategic Behaviour and the Rules for International Taxation of Capital. The Economic Journal, 1989, vol. 99, no. 398, pp. 1099-1111.

[5] Buus, T. - Brada, J. (2008): On the Necessity of Using Average Cost as a Base for Transfer Price. European Financial and Accounting Journal, 2008, vol. 3, no. 3, pp. 79-94.

[6] Eden, L. - Rodriguez, P. (2004): How Weak Are the Signals? International Price Indices and Multinational Enterprises. Journal of International Business Studies, 2004, vol. 35, no. 1, pp. 61-74.

[7] Gatti, J. F. - Grinnell, D. J. - Jensen, O. W. (1997): Replicating a Free Market for Internal Transactions: An Alternative Approach to Transfer Pricing. Journal of Business \& Economic Studies, 1997, vol. 3, no 2, pp. 43-62.

[8] Gresik, T. A. (2001): The Taxing Task of Taxing Transnationals. Journal of Economic Literature; 2001; vol. 39, no. 3, pp. 800-838.

[9] Haufler, A. - Schjelderup, G. (2000): Corporate Tax Systems and Cross Country Profit Shifting. Oxford Economic Papers, 2000, vol. 52, no. 2, pp. 306-325.

[10] Hirshleifer, J. (1956): On the Economics of Transfer Pricing. Journal of Business, 1956, vol. 29, no. 3, pp.172-184.

[11] Keen, M. - Wildasin, D. (2004): Pareto-Efficient International Taxation. American Economic Review, 2004, vol. 94, no. 1, pp. 259275.

[12] Mansori, K. S. - Weichenrieder, A. J. (1999): Tax Competition And Transfer Pricing Disputes [on-line], New York, Social Science Research Network, c1999, [cit. ${ }^{\text {st }}$ October, 2009], <http://ssrn.com/abstract=199672>. 
[13] OECD (2001): Transfer Pricing Guidelines for Multinational Enterprises and Tax Administrations. Paris, Organisation for Economic Co-operation and Development, 2001.

[14] Pappas, J. L. - Brigham, E. F. - Hirschey, M. (1983): Managerial Economics. Dryden Press. Chicago, 1983.

[15] Raimondos-Moller, P. - Scharf, K. (2002): Transfer pricing rules and competing governments. Oxford Economic Papers, 2002, vol. 54, no. 2. pp. 230-246.

[16] Sansing, R. (1999): Relationship-Specific Investments and the Transfer Pricing Paradox. Review of Accounting Studies, 1999, vol. 4, no. 2. pp. 119-134.

[17] Schjelderup, G. - Weichenrieder, A. J. (1999): Trade, Multinationals and Transfer Pricing Regulation. Canadian Journal of Economics, 1999, vol. 32, no. 3, pp. 817-834.

[18] Schmallenbach, E. (1908): Über Verrechnungspreise. Zeitschrift für handelswissenschaftliche Forschung 1908, vol. 3, no. 4, pp. 165-185.

[19] Soukup, J. (2003): Mikroekonomická analýza - vybrané kapitoly. Melandrium, Slaný, 2003.

[20] Wellisch, D. (2003): Internationale Verrechnungspreismethoden, Neutralität und die Gewinne multinationaler Unternehmen. Jahrbücher für Nationalökonomie und Statistik, 2003, vol. 223, no. 3. pp. 332-359.

[21] Steven, R. (2005): Advanced Linear Algebra. New York, Springer, 2005. 


\title{
Detection of Possible Tax-Evasive Transfer Pricing in Multinational Enterprises
}

\author{
Jaroslav BRADA - Tomáš BUUS
}

\begin{abstract}
In this paper we analyze possible source of tax evasion in the multinational entity (hereinafter "MNE"). We show that the tax obligation of the whole MNE depends on the ownership structure of companies, which form MNE and that the structure could be described by matrix form. Therefore the basic tax optimization tasks of MNE via transfer pricing can be understood as linear programming problems. In addition we propose a way to identify possible tax evasion realized via transfer pricing in MNE.
\end{abstract}

Key words: Transfer prices; Tax evasion; Tax authorities; Multinational entities; Mathematical taxation; Linear programming.

JEL classification: D21, D29, G39. 